\title{
Agronomic Performance and Multivariate Analysis Applied to Three-Waycross Maize Hybrids
}

\author{
Tiago Corazza da Rosa ${ }^{1}$, Ivan Ricardo Carvalho ${ }^{1}$, Vinícius Jardel Szareski ${ }^{1}$, Alan Junior de Pelegrin ${ }^{1}$, \\ Mauricio Horbach Barbosa ${ }^{2}$, Nathan Lobler dos Santos ${ }^{1}$, Tamires da Silva Martins ${ }^{1}$, \\ Adriel Somavilla Uliana $^{1} \&$ Velci Queiróz de Souza ${ }^{3}$ \\ ${ }^{1}$ Universidade Federal de Pelotas, Campus Capão do Leão, Capão do Leão, RS, Brazil \\ ${ }^{2}$ Universidade Federal de Santa Maria, Campus de Frederico Westphalen, Frederico Westphalen, RS, Brazil \\ ${ }^{3}$ Universidade Federal do Pampa, Dom Pedrito, RS, Brazil \\ Correspondence: Ivan Ricardo Carvalho, Universidade Federal de Pelotas, Campus Capão do Leão, CEP \\ 96050-500, Capão do Leão, RS, Brazil. Tel: 55-9640-8757. E-mail: carvalho.irc@gmail.com
}

Received: January 24, 2018

Accepted: March 12, $2018 \quad$ Online Published: April 15, 2018

doi:10.5539/jas.v10n5p319

URL: https://doi.org/10.5539/jas.v10n5p319

\begin{abstract}
The aim of this wok was to evaluate the agronomic performance of three-waycross maize hybrids grown in different environments, to determine linear associations and to employ multivariate analysis for the measured traits. The experimental design used was randomized blocks in factorial scheme, arranged in three replicates. The three-way cross maize hybrids evaluated evidence phenotypic variability for the traits spike diameter, spike length, number of rows with grains, number of grains per row, cob mass and spike grains mass. The growing environment of Campos Borges-RS favors the increment of spike diameter, number of grains per row, spike mass, cob diameter, cob mass, mass of a thousand grains, spike grains mass and grain yield. Significant interactions between three-way cross maize hybrids and growing environments are verified for plant height, spike insertion height and prolificity. The traits spike diameter, mass of a thousand grains and mass of grains per spike present positive correlation with maize grain yield. The distinction of three-way cross hybrids is based on spike insertion height, spike diameter, plant height and mass of a thousand grains. The hybrids $2 B 688$ HX® and $2 \mathrm{~A} 55 \mathrm{HX}{ }^{\circledR}$ are genetically closer, according to the biometric approach of canonical variables.
\end{abstract}

Keywords: Zea mays L., strategy of breeding, genotype $\times$ environment interaction

\section{Introduction}

Maize (Zea mays L.) has an outstanding role in the world agribusiness scenario because it provides many products for human and animal diet, also being used for ethanol production and other branches of industry (Demetrio, 2008). Maize is the second most cultivated crop in the world, with 177 million hectares sown in the 2015/2016 growing season (USDA, 2016). An area of 16.2 million hectares was grown in Brazil during the 2015/2016 agricultural year, with production of 84 million tons of grains, ranking the country as third larger producer of this cereal (USDA, 2016). The southern region produced $31 \%$ of the national total, playing important role in the agricultural scenario (CONAB, 2016). Due to the large number of maize genotypes available for farmers, the decision making about which is the most suitable for their economic and technological conditions becomes crucial. Hence, it is necessary to carry out trials of agronomic performance to evaluate the genotypes recommended for specific areas of cultivation, generating trustworthy and useful information for farmers.

There are many genetic bases of maize genotypes available in the market. The single cross hybrids are originated from crossing between two homozygous lineages, enhanced by the specific combining ability and heterosis effects (Nardino et al., 2016; Demari et al., 2016). Single cross hybrids are potentially more productive than the other types of hybrids, however, they demand improved environment and cultural traits. Three-waycrosshybrids results from crossing between a homozygous lineage and a single cross hybrid, being phenotypically uniform, with productive potential intermediate to single and double cross hybrids, however, presenting better adaptability to environment variations due to its greater genetic base, compared to single cross hybrids (Singh et al., 2012). 
The double cross hybrids come from the cross between two single cross hybrids, and due to their broad genetic constitution, they present greater stability and lower cost of production (Emygdio et al., 2007).

One of the major obstacles to maize breeding programs is the instability of genotypes behavior due to environmental variations (Szareski et al., 2018). Thus, the comprehension of genotype $\times$ environment interaction $(\mathrm{G} \times \mathrm{A})$ becomes indispensable for maize breeding and genotypes recommendation (Maia, 2006). Grain yield in maize is determined by the genotype's genetic constitution and its plasticity in different environment conditions. Considering different environments, importance must be given for $\mathrm{G} \times \mathrm{E}$ interaction (Cruz et al., 2012; Szareski et al., 2017; Carvalho et al., 2017). Growing environment is constituted by meteorological and edaphic elements, and cultural traits, which may differentially influence genotypes behavior (Galon et al., 2010). Grain yield is a complex trait determined by association of severalcharacters and expression of many genes, being highly dependent of environment conditions (Ribeiro, 2012).

In order to comprehend genotypes inconsistencies in different environments, the multivariate analyses are to be employed, which consider the performance of different traits, generating a single tendency (Costa, 2010). These analyses applied in the dynamics of a breeding program may aid to distinguish genotypes more efficiently (Oliboni, 2009). The employment of multivariate techniques allows to comprehend genetic differentiations among genotypes, and to use this information to boost the crop breeding (Hallauer et al., 2010; Uitzil et al., 2016). Therefore, the aim of this wok was to evaluate the agronomic performance of three-way cross maize hybrids grown in different environments, to determine linear associations and to employ multivariate analysis for the measured traits.

\section{Material and Methods}

The experiment was carried out during the 2014/2015 agricultural year, in two growing environments, which are characterized in the Table 1.

Table 1. Characterization of the growing environments regarding geographic coordinates, altitude, soil type and climate

\begin{tabular}{llllll}
\hline Growing environment & Latitude & Longitude & Altitude $(\mathrm{m})^{\circ}$ & Soil type $^{1}$ & Climate $^{2}$ \\
\hline Campos Borges, RS & $28^{\circ} 52^{\prime} 31^{\prime \prime} \mathrm{S}$ & $53^{\circ} 00^{\prime} 55^{\prime \prime} \mathrm{O}$ & 513 & Dark red latosol & Cfa subtropical \\
Salto do Jacuí, RS & $29^{\circ} 5^{\prime} 16^{\prime \prime} \mathrm{S}$ & $53^{\circ} 12^{\prime} 27^{\prime \prime} \mathrm{O}$ & 306 & Dark red latosol & Cfa subtropical \\
\hline
\end{tabular}

Note. ${ }^{1}$ Classification according to methodology proposed by Santos et al. (2006); ${ }^{2}$ Climatic classification according to Maluf (2000).

The experimental design used was randomized blocks in factorial scheme, being two growing environments (Campos Borges, RS and Salto do Jacuí, RS) $\times$ six three-way cross maize hybrids $\left(\mathrm{DKB566VTPRO}{ }^{\circledR}\right.$, $\left.2 \mathrm{~B} 339 \mathrm{Hx}^{\circledR}, 2 \mathrm{~A} 55 \mathrm{Hx}^{\circledR}, 2 \mathrm{~B} 688 \mathrm{Hx}^{\circledR}, \mathrm{AG}^{\circledR} 011^{\circledR}, \mathrm{KSP}^{\circledR} 248^{\circledR}\right)$, arranged in three replicates. Direct sowing system was used, with base fertilization of $300 \mathrm{~kg} \mathrm{ha}^{-1}$ of NPK in the formula 10-20-20. For topdressing, it was used 200 $\mathrm{kg} \mathrm{ha}{ }^{-1}$ of urea at $\mathrm{V}_{4}$ and $\mathrm{V}_{6}$ vegetative stages (Fancelli \& Dourado Neto, 2000). The sowing density for all genotypes was 75,000 plants per hectare. The experimental units were composed by four rows of five meters length, spaced 0.5 meters between rows. The useful plot was composed by two central lines, discarding 0.5 meters of each extremity to minimize border effects. The management of pests and weeds was carried preventively, in order to minimize biotic effects.

The traits of agronomic interest were determined based on the methodology proposed by Carvalho et al. (2014), sampling three plants aleatory in each experimental unity. The evaluated traits were: Plant height (PH), results in centimeters $(\mathrm{cm})$; Spike insertion height $(\mathrm{SH})$, results in meters $(\mathrm{m})$; Spike diameter $(\mathrm{SD})$, results in millimeters $(\mathrm{mm})$; Spike length $(\mathrm{SL})$, results in centimeters $(\mathrm{cm})$; Spike mass $(\mathrm{SM})$, results in grams $(\mathrm{g})$; number of rows with grains in the spike (NRG), results in units; number of grains per row (NGR), results in units; cob diameter (CD), results in millimeters (mm); cob mass (CM), results in grams (g); mass of grains per spike (MGS), results in grams $(\mathrm{g})$; mass of a thousand grains (MTG), results expressed in grams (g); grain yield (GY), results in kg $\mathrm{ha}^{-1}$.

The data was subjected to analysis of varianceby the $\mathrm{F}$ test at $5 \%$ of probability. The variance analysis's assumptionswere performed by the Shapiro-Wilk (1965) test in order to reveal the data normality. The homogeneity of residual variances was verified by the Hartley test (Ramalho et al., 2012). The joint analysis of variation sources was performed to revealinteractions between growing environments and three-way-cross-maize 
hybrids. In case of interaction, the effects were sliced. Traits that did not reveal significant interaction were sliced for principal effects for each factor trough Tukey test at $5 \%$ of probability. Posteriorly, it was performed the Pearson's linear correlation analysis for both growing environments in order to reveal the tendency of associations between traits. The next step was to perform the analysis of relative contribution by Singh (1981), and canonical variates (Cruz et al., 2014). All statistical procedures were performed though the Genes software (Cruz, 2013).

\section{Results and Discussion}

The analysis of variance revealed significant interaction for growing environments $\times$ three-way cross maize hybrids at $5 \%$ of probability for plant height $(\mathrm{PH})$, spike insertion height $(\mathrm{SH})$ and prolificity (PRO) (Tables 4, 5 and 6). Evaluating grain yield components of maize hybrids grown in four different environments from southern Brazil, Nardino et al. (2016) found no significant interaction. Paixão (2008) verified significant genotype $\times$ environment interaction for plant height and spike insertion height, evaluating genotypes of broad genetic basis.

Regarding the variation source three-way cross maize hybrids, significant differences were evidenced for the traits spike diameter (DE), spike length (SL), number of rows with grains per spike (NRG), number of grains per row (NGR), cob mass (CM) and mass of grains per spike (MGS) (Table 2).

Table 2. Averages of the traits spike diameter (SD), spike length (SL), number of rows with grains per spike (NRG), number of grains per row (NGR), spike mass(SM), cob diameter (CD), cob mass (CM), mass of a thousand grains (MTG), mass of grains per spike (MGS) and grain yield (GY) for the source of variation three-waycross maize hybrids

\begin{tabular}{|c|c|c|c|c|c|}
\hline Three-way cross maize hybrids & $\mathrm{SD}(\mathrm{mm})$ & $\mathrm{SL}(\mathrm{cm})$ & NRG (unid.) & NGR (unid.) & SM (g) \\
\hline DKB 566 VTPRO $^{R}$ & $44.9 \mathrm{ab}$ & $16.57 \mathrm{ab}$ & $14.77 \mathrm{c}$ & $36.22 \mathrm{a}$ & $145.82 \mathrm{a}$ \\
\hline 2B $339 \mathrm{Hx}^{\circledR}$ & $47.73 \mathrm{ab}$ & $16.68 \mathrm{ab}$ & $15.77 \mathrm{bc}$ & $34.94 \mathrm{a}$ & $184.88 \mathrm{a}$ \\
\hline $2 \mathrm{~A} 55 \mathrm{Hx}^{\circledR}$ & $42.29 \mathrm{~b}$ & $15.34 \mathrm{bc}$ & $17.10 \mathrm{ab}$ & $30.66 \mathrm{ab}$ & $141.27 \mathrm{a}$ \\
\hline $2 \mathrm{~B} 688 \mathrm{Hx}^{\circledR}$ & $46.43 \mathrm{ab}$ & $13.79 \mathrm{c}$ & $18.22 \mathrm{a}$ & $28.61 \mathrm{~b}$ & $136.13 \mathrm{a}$ \\
\hline AG $8011^{\circledR}$ & $44.80 \mathrm{ab}$ & $14.95 \mathrm{bc}$ & $16.68 \mathrm{abc}$ & $33.61 \mathrm{ab}$ & $129.46 \mathrm{a}$ \\
\hline KSP $3248^{\circledR}$ & $49.48 \mathrm{a}$ & $18.00 \mathrm{a}$ & $15.88 \mathrm{bc}$ & $36.16 \mathrm{a}$ & $203.70 \mathrm{a}$ \\
\hline${ }^{+} \mathrm{CV}(\%)$ & 7.31 & 9.29 & 7.72 & 10.69 & 30.94 \\
\hline${ }^{++} \mathrm{R}^{2}$ & 0.54 & 0.53 & 0.50 & 0.50 & 0.48 \\
\hline Three-way cross maize hybrids & $\mathrm{CD}(\mathrm{mm})$ & CM (g) & MTG (g) & MGS (g) & $\mathrm{GY}\left(\mathrm{kg} \mathrm{ha}^{-1}\right)$ \\
\hline DKB 566 VTPRO $^{\circledR}$ & $25.5 \mathrm{a}$ & $21.01 \mathrm{~b}$ & $213.16 \mathrm{a}$ & $114.75 \mathrm{ab}$ & $4179.00 \mathrm{a}$ \\
\hline 2B $339 \mathrm{Hx}^{\circledR}$ & $27.22 \mathrm{a}$ & $35.53 \mathrm{ab}$ & $257.15 \mathrm{a}$ & $130.37 \mathrm{ab}$ & $6497.00 \mathrm{a}$ \\
\hline $2 \mathrm{~A} 55 \mathrm{Hx}^{\circledR}$ & $26.93 \mathrm{a}$ & $28.49 \mathrm{ab}$ & $207.21 \mathrm{a}$ & $93.60 \mathrm{~b}$ & $3552.00 \mathrm{a}$ \\
\hline $2 \mathrm{~B} 688 \mathrm{Hx}^{\circledR}$ & $28.18 \mathrm{a}$ & $26.38 \mathrm{ab}$ & $220.05 \mathrm{a}$ & $96.68 \mathrm{ab}$ & $3748.00 \mathrm{a}$ \\
\hline AG $8011^{\circledR}$ & $29.94 \mathrm{a}$ & $20.62 \mathrm{~b}$ & $205.36 \mathrm{a}$ & $103.45 \mathrm{ab}$ & $5104.00 \mathrm{a}$ \\
\hline KSP $3248^{\mathbb{R}}$ & $27.98 \mathrm{a}$ & $42.44 \mathrm{a}$ & $284.65 \mathrm{a}$ & $159.68 \mathrm{a}$ & $5827.00 \mathrm{a}$ \\
\hline${ }^{+} \mathrm{CV}(\%)$ & 6.03 & 34.88 & 25.98 & 30.74 & 36.32 \\
\hline${ }^{++} \mathrm{R}^{2}$ & 0.48 & 0.53 & 0.44 & 0.51 & 0.51 \\
\hline
\end{tabular}

Note. * Means followed by the same lowercase letter in the column do not statistically differ by Tukey at $5 \%$ of probability; ${ }^{+}$Coefficient of variation; ${ }^{++}$Coefficient of determination.

The variation source growing environments (Table 3) revealed significant differences for the traits spike diameter (SD), number of grains per row (NGR), spike mass (SM), cob diameter (CD), cob mass (CM), mass of a thousand grains (MTG), mass of grains per spike (MGS) and grain yield (GY).

The hybrid KSP 3248 presented the highest magnitude for the traits SD, SL, SM, CM, MTG and MGS, differing from the hybrid $2 \mathrm{~A} 55 \mathrm{Hx}^{\circledR}$ for SD, from the hybrids $2 \mathrm{~A} 55 \mathrm{Hx}, 2 \mathrm{~B} 688 \mathrm{Hx}^{\circledR}$ and AG8011 for SL, from the hybrids DKB566VTPRO $^{\circledR}$ and AG8011 for CM, and from the hybrid $2 \mathrm{~A} 55 \mathrm{Hx}^{\circledR}$ for MGS. The hybrid $2 \mathrm{~B} 688 \mathrm{Hx}^{\circledR}$ presented the highest magnitude for the trait NRG, statistically differing from the hybrids DKB566VTPRO ${ }^{\circledR}$ and $\mathrm{KSP} 3248^{\circledR}$.

The growing environment of Campos Borges, RS presented positive influence for incrementing grain yield of the evaluated three-way cross maize hybrid. 
Table 3. Averages of the traits spike diameter (SD), spike length (SL), number of rows with grains per spike (NRG), number of grains per row (NGR), spike mass (SM), cob diameter (CD), cob mass (CM), mass of a thousand grains (MTG), mass of grains per spike (MGS) and grain yield (GY) for the source of variation growing environment

\begin{tabular}{llllll}
\hline Growing environment & SD $(\mathrm{mm})$ & SL $(\mathrm{cm})$ & NRG (unid.) & NGR (unid.) & SM (g) \\
\hline Campos Borges-RS & $47.90 \mathrm{a}$ & $15.89 \mathrm{a}$ & $16.40 \mathrm{a}$ & $34.63 \mathrm{a}$ & $186.69 \mathrm{a}$ \\
Salto do Jacuí-RS & $43.72 \mathrm{~b}$ & $15.88 \mathrm{a}$ & $16.40 \mathrm{a}$ & $32.11 \mathrm{~b}$ & $127.07 \mathrm{~b}$ \\
${ }^{+} \mathrm{CV}(\%)$ & 7.31 & 9.29 & 7.72 & 10.69 & 30.94 \\
${ }^{++} \mathrm{R}^{2}$ & 0.54 & 0.53 & 0.50 & 0.50 & 0.48 \\
\hline Growing environment & $\mathrm{CD}(\mathrm{mm})$ & $\mathrm{CM}(\mathrm{g})$ & $\mathrm{MTG}(\mathrm{g})$ & $\mathrm{MGS}(\mathrm{g})$ & $\left.\mathrm{GY}^{(\mathrm{kg} \mathrm{h}} \mathrm{ha}^{-1}\right)$ \\
\hline Campos Borges-RS & $28.10 \mathrm{a}$ & $34.40 \mathrm{a}$ & $264.73 \mathrm{a}$ & $138.61 \mathrm{a}$ & $5871.10 \mathrm{a}$ \\
Salto do Jacuí-RS & $26.09 \mathrm{~b}$ & $23.76 \mathrm{~b}$ & $197.80 \mathrm{~b}$ & $94.24 \mathrm{~b}$ & $3764.90 \mathrm{~b}$ \\
${ }^{+} \mathrm{CV}(\%)$ & 6.03 & 34.88 & 25.98 & 30.74 & 36.32 \\
${ }^{++} \mathrm{R}^{2}$ & 0.48 & 0.53 & 0.44 & 0.51 & 0.51 \\
\hline
\end{tabular}

Note. *Means followed by the same lowercase letter in the column do not statistically differ by Tukey at 5\% of probability; ${ }^{+}$Coefficient of variation; ${ }^{++}$Coefficient of determination.

These differentiations may occur due to variation in altitude between environments, thermal amplitude, energy balance, light quality on the crop canopy, and soil and climatic conditions. Elevated temperatures during the night promote higher energetic consumption due to the increment of cellular respiration, resulting in lower balance of photoassimilates and consequently, reducing grain yield (Fancelli \& Dourado Neto, 2000; Carvalho et al., 2016).

Regarding the trait PH (Table 4), the hybrid 2B339Hx ${ }^{\circledR}$ was superior in the growing environment of Campos Borges-RS. In the environment of Salto do Jacuí-RS, the hybrids $2 \mathrm{~B} 339 \mathrm{Hx}{ }^{\circledR}, 2 \mathrm{~B} 688 \mathrm{Hx}^{\circledR}$ and $\mathrm{AG} 8011^{\circledR}$ were superior. This differential behavior is explained because plant height is a quantitative trait controlled by many genes, with elevated influence of the environment on phenotype and being highly dependent of management techniques, population density (Abuzar et al., 2011; Szareski et al., 2017), cycle duration, as early genotypes may express shorter plants (Cruz et al., 2010). Spike insertion height (Table 4) is closely related to losses in mechanic harvest, therefore, uniformity of this trait is essential for an efficient mechanic harvest. Li et al. (2007) affirm that high values of spike insertion height strongly contribute for lodging in maize field. In the environment of Campos Borges-RS, the hybrid $2 \mathrm{~B} 339 \mathrm{Hx}^{\circledR}$ was superior to the others, however, in the growing environment of Salto do Jacuí-RS, the superior genotypes were DKB566VTPRO ${ }^{\circledR}, 2 \mathrm{~A} 55 \mathrm{Hx}^{\circledR}$ and $2 \mathrm{~B}^{\circledR} 88 \mathrm{Hx}{ }^{\circledR}$.

Table 4. Averages for growing environments $\times$ three-way cross maize hybrids interaction for the traits plant height $(\mathrm{PH})$, spike insertion height $(\mathrm{SH})$ and prolificity $(\mathrm{PRO})$

\begin{tabular}{|c|c|c|c|c|c|c|}
\hline \multirow{4}{*}{ Three-way cross maize hybrids } & \multicolumn{6}{|c|}{ Growing environments } \\
\hline & \multicolumn{2}{|c|}{$\mathrm{PH}(\mathrm{m})$} & \multicolumn{2}{|c|}{$\mathrm{SH}(\mathrm{m})$} & \multicolumn{2}{|c|}{ PRO (Unid.) } \\
\hline & Campos & Salto do & Campos & Salto do & Campos & Salto do \\
\hline & Borges-RS & Jacuí-RS & Borges-RS & Jacuí-RS & Borges-RS & Jacuí-RS \\
\hline DKB 566 VTPRO ${ }^{\circledR}$ & $2.28 \mathrm{abA}$ & $2.02 \mathrm{bB}$ & $1.2 \mathrm{bA}$ & $0.96 \mathrm{~dB}$ & $0.98 \mathrm{aA}$ & $0.97 \mathrm{aA}$ \\
\hline 2B $339 \mathrm{HX}^{\circledR}$ & $2.34 \mathrm{aA}$ & $2.17 \mathrm{aB}$ & $1.36 \mathrm{aA}$ & $1.32 \mathrm{aA}$ & $0.98 \mathrm{aA}$ & $0.88 \mathrm{abA}$ \\
\hline $2 \mathrm{~A} 55 \mathrm{HX}^{\circledR}$ & $1.95 \mathrm{bB}$ & $2.12 \mathrm{abA}$ & $0.97 \mathrm{eA}$ & $1.1 \mathrm{cdA}$ & $1.07 \mathrm{aA}$ & $0.78 \mathrm{bB}$ \\
\hline 2B688 $\mathrm{HX}^{\circledR}$ & $2.03 \mathrm{bB}$ & $2.16 \mathrm{aA}$ & $1.04 \mathrm{de} A$ & $1.15 \mathrm{bcA}$ & $0.99 \mathrm{aA}$ & $0.91 \mathrm{abA}$ \\
\hline AG $8011^{\circledR}$ & $2.20 \mathrm{bA}$ & $2.18 \mathrm{aA}$ & $1.19 \mathrm{bcA}$ & $1.22 \mathrm{abcA}$ & $0.95 \mathrm{aA}$ & $0.98 \mathrm{aA}$ \\
\hline KSP $3248^{\circledR}$ & $2.05 \mathrm{cA}$ & $2.04 \mathrm{bA}$ & $1.19 \mathrm{bcA}$ & $1.21 \mathrm{abcA}$ & $0.97 \mathrm{aA}$ & $0.95 \mathrm{aA}$ \\
\hline$+\mathrm{CV} \%$ & 2.90 & & 7.37 & & 9.07 & \\
\hline$++\mathrm{R}^{2}$ & 0.83 & & 0.76 & & 0.59 & \\
\hline
\end{tabular}

Note. ${ }^{*}$ Means followed by the same lowercase letter in the column and uppercase letter in the row do not statistically differ by Tukey at $5 \%$ of probability; ${ }^{+}$Coefficient of variation; ${ }^{++}$Coefficient of determination. 
There were no differences among genotypes for the trait Prolificity (PRO) (Table 4) in the growing environment of Campos Borges-RS. However, in the growing environment of Salto do Jacuí-RS, the hybrid 2A55Hx reduced this trait in $27 \%$. Prolific plants are generally more tolerant to adverse conditions due to their plasticity under stress situations, and may positively influence grain yield when population density is below the ideal (Sangoi et al., 2010). The optimization of number of grains per unity of area is possible through the increment of populational density and the number of spikes per plant, depending on the genotype's genetic base (Lopes et al., 2007; Szareski et al., 2016).

The Pearson's linear correlation performed for 13 traits revealed 78 associations, of which 43 were significant (Table 5). Correlation is a statistic estimator that measures the level of association between two variables. Thereby, correlated traits occur when a variation in one trait is followed by a simultaneous variation in the other (Ramalho et al., 2012). The knowledge about phenotypic, genetic and environment correlation is essential for simultaneous selection of more than one trait, or when the character of interest presents low heritability or is difficult to be measured (Falconer \& Mackay, 1996).

The trait PH is strongly and positively correlated with $\mathrm{SH}(\mathrm{r}=0.75)$ due to the tendency of spike height to variate in accordance to plant height. Thus, higher plants tend to have spikes farther from the soil surface.The trait SH presents moderate and positive correlation with SD $(r=0.45), \mathrm{SM}(\mathrm{r}=0.39), \mathrm{CM}(\mathrm{r}=0.35), \mathrm{MTG}(\mathrm{r}=$ $0.41)$, MG $(r=0.44)$ and GY $(r=0.46)$, being a morphological trait that possible may be used in indirect selection of grain yield components. The trait SD presented strong and positive correlation with $\mathrm{SM}(\mathrm{r}=0.86)$, $\mathrm{CM}(\mathrm{r}=0.85)$, MTG $(\mathrm{r}=0.86), \mathrm{MG}(\mathrm{r}=0.90), \mathrm{CD}(\mathrm{r}=0.73)$ and $\mathrm{GY}(\mathrm{r}=0.62)$, and moderate and positive correlations with SL $(r=0.37)$ and NGR $(r=0.43)$. Thus, plants with wider spikes tend to present increment in several grain yield components, such as mass of grains per spike and mass of a thousand grains, and consequently, greater grain yield. The trait SL evidenced strong and positive correlation with NGR $(r=0.78)$, moderate and positive with SM $(r=0.57), \mathrm{CM}(\mathrm{r}=0.53)$, MTG $(\mathrm{r}=0.46)$ and MG $(\mathrm{r}=0.59)$. Plants with longer spikes tend to present higher number of grains per row, thus, spikes with more grains, resulting in an increment of cob and spike mass.

Table 5. Estimates of Pearson's linear correlation for the traits plant height (PH), spike insertion height (SH), prolificity (PRO), spike diameter (SD), spike length (SL), number of rows with grains per spike (NRG), number of grains per row (NGR), spike mass (SM), cob diameter (CD), cob mass (CM), mass of a thousand grains (MTG), mass of grains per spike (MGS) and grain yield (GY)

\begin{tabular}{|c|c|c|c|c|c|c|c|c|c|c|c|c|}
\hline & $\mathrm{SH}$ & PRO & SD & $\mathrm{SL}$ & NRG & NGR & SM & $\mathrm{CD}$ & $\mathrm{CM}$ & MTG & MGS & GY \\
\hline $\mathrm{PH}$ & $0.75^{* *}$ & $-0.12 *$ & 0.10 & 0.01 & -0.23 & 0.18 & 0.07 & -0.14 & -0.08 & 0.11 & 0.14 & 0.32 \\
\hline $\mathrm{SH}$ & - & -0.03 & $0.45^{* *}$ & 0.31 & -0.24 & 0.31 & $0.39 *$ & 0.12 & $0.35^{*}$ & $0.41 *$ & $0.44 * *$ & $0.46^{*}$ \\
\hline PRO & & - & 0.27 & 0.06 & -0.02 & 0.10 & 0.31 & 0.31 & 0.20 & 0.18 & 0.20 & 0.32 \\
\hline SD & & & - & $0.37^{*}$ & 0.00 & $0.43 * *$ & $0.86^{* *}$ & $0.73 * *$ & $0.85^{* *}$ & $0.86^{* *}$ & $0.90 * *$ & $0.62 * *$ \\
\hline SL & & & & - & -0.49 & $0.78 * *$ & $0.57 * *$ & $0.10 * *$ & $0.53 * *$ & $0.46^{* *}$ & $0.59^{*}$ & 0.27 \\
\hline NRG & & & & & - & $-0.49 * *$ & -0.14 & 0.29 & -0.07 & -0.21 & -0.21 & -0.20 \\
\hline NGR & & & & & & - & $0.57 * *$ & 0.18 & $0.43 * *$ & $0.48 * *$ & $0.67 * *$ & $0.34 *$ \\
\hline SM & & & & & & & - & $0.64 * *$ & $0.89 * *$ & $0.88 * *$ & $0.92 * *$ & $0.52 * *$ \\
\hline $\mathrm{CD}$ & & & & & & & & - & $0.71 * *$ & $0.53 * *$ & $0.57 * *$ & $0.38 *$ \\
\hline $\mathrm{CM}$ & & & & & & & & & - & $0.84 * *$ & $0.86^{* *}$ & $0.54 * *$ \\
\hline MTG & & & & & & & & & & - & $0.90 * *$ & $0.60 * *$ \\
\hline MGS & & & & & & & & & & & - & $0.61 * *$ \\
\hline
\end{tabular}

Note. ${ }^{*}$ Significant values at $5 \%$ of probability; ${ }^{* *}$ Significant values at $1 \%$ of probability.

The trait NGR correlated moderately and positively with SM $(r=0.57)$, CM $(r=0.43)$ and MTG $(r=0.48)$, and strongly and positively with MG $(r=0.67)$, however it presented correlation of weak and positive magnitude with GY $(r=0.34)$. Spikes with more grains per row tend to be longer, presenting greater mass of grains, incrementing grain yield. Number of grains per row is the yield component that most contribute for grain yield in maize open pollinated varieties. However, prolificity, number of rows with grains per spike and mass of grains are determinant for grain yield (Balbinoti Junior et al., 2005). 
The trait SM presented very strong and positive correlation with CM $(r=0.89)$, MTG $(r=0.88)$, MG $(r=0.92)$, and moderate and positive with $\mathrm{CD}(\mathrm{r}=0.64)$ and GY $(\mathrm{r}=0.52)$. Spike mass is given by the sum of spike grains mass and cob mass, justifying the positive relation evidenced for these components. Performing similar study, Lopes et al. (2007) verified that mass of grains per spike is positively correlated with eight of the nine explanatory variables. Besides, $75 \%$ of the explanatory variables are positively correlated among themselves, evidencing the complexity of relations in maize spike traits. This fact implies the difficulty of selecting maize genotypes because it jeopardizes the identification of characteristics of more interest. Therefore, the ideal procedure was to slice correlations in direct and indirect effects in order to evaluate the degree of importance of each explanatory trait on the dependent variable (Daros et al., 2004; Ferrari et al., 2016).

The interest on evaluating the relative contribution of traits for diversity lays on the possibility to discard characters which poorly contribute to discriminate the genotypes, reducing labor, time and money spent on experimentation (Rotili et al., 2012; Nardino et al., 2017). The dispensable traits in studies of genetic divergence are those with few variations among genotypes, or redundant for being correlated with other traits, such as plant height and spike height, which commonly are measured in maize breeding programs (Miranda et al. 2003). In this study, the evaluated traits (Table 5) SH (20.083\%), SD (18.373\%), PH (14.414\%), MTG (10.887\%) presented the higher percentages of contributions, confronting the previous affirmation. Analyzing maize genotypes, Silva and Peluzio (2014) concluded that traits with higher contribution for divergence were plant height $(24.63 \%)$, plant green mass $(10.28 \%)$, spike diameter $(11.32 \%)$ and number of grains per row $(9.11 \%)$, totalizing $55.34 \%$ of contribution. In the three-way cross maize hybrids evaluated, it is suggested to discard CD (1.225\%), PRO (1.454\%), CB (2.035\%), NGR (3.412\%) and MG (3.367\%) due to their low percentage of contribution for genotypes' discrimination.

The canonical variates analysis is an alternative procedure to evaluate the degree of similarity among hybrids, considering both the residual covariance matrix and the covariance between phenotypic means of the evaluated traits. This technique is based on a large number of correlated original characteristics, achieving linear combinations in such way the correlation between them is null (Kendall, 1950). Hence, Table 6 and Figure 1 represents the grouping of six three-waycross maize hybrids for the 13 measured traits.

Table 6. Relative contribution for diversity of six three-way cross maize hybrids in two growing environments by Singh (1981), considering the following traits: plant height (PH), spike insertion height (SH), prolificity (PRO), spike diameter (SD), spike length (SL), number of rows with grains per spike (NRG), number of grains per row (NGR), spike mass (SM), cob diameter (CD), cob mass (CM), mass of a thousand grains (MTG), mass of grains per spike (MGS) and grain yield (GY)

\begin{tabular}{lll}
\hline Trait & S.J & Value (\%) \\
\hline PH & 93.64 & 14.41 \\
SH & 130.47 & 20.08 \\
PRO & 9.44 & 1.45 \\
SD & 119.36 & 18.37 \\
SL & 62.34 & 9.56 \\
NRG & 37.72 & 5.80 \\
NGR & 22.17 & 3.41 \\
SM & 38.31 & 5.89 \\
CD & 7.96 & 1.22 \\
CM & 13.22 & 2.03 \\
MTG & 70.73 & 10.88 \\
MGS & 21.87 & 3.36 \\
GY & 22.37 & 3.44 \\
\hline
\end{tabular}




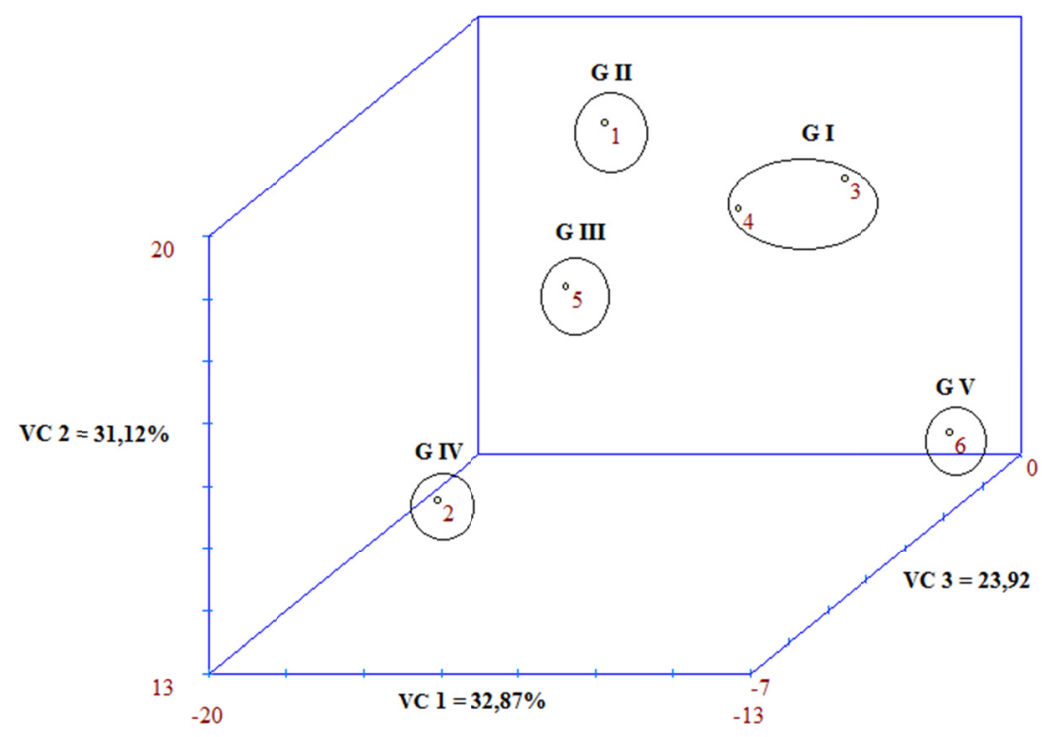

Figure 1. Graphic representation of the canonical variates obtained through evaluation of thirteen traits of

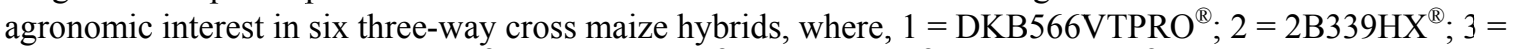
$2 \mathrm{~A} 55 \mathrm{HX}^{\circledR} ; 4=2 \mathrm{~B} 688 \mathrm{HX}^{\circledR} ; 5=\mathrm{AG}^{\circledR} 011^{\circledR} ; 6=\mathrm{KSP}^{\circledR} 248^{\circledR}$

The hybrids $2 \mathrm{~B} 688 \mathrm{Hx}^{\circledR}$ and $2 \mathrm{~A} 55 \mathrm{Hx}^{\circledR}$ were arranged in the same group of canonical variates (group I). The means observed for these genotypes are similar. Therefore, the phenotypic similarity evidenced is due to germplasm from the same breeder, and there might be a degree of relatedness between their parent lineages. The other genotypes were organized in four distinct groups because of their phenotypic differences.

\section{Conclusion}

The three-way cross maize hybrids evaluated evidence phenotypic variability for the traits spike diameter, spike length, number of rows with grains, number of grains per row, cob mass and spike grains mass.

The growing environment of Campos Borges-RS favors the increment of spike diameter, number of grains per row, spike mass, cob diameter, cob mass, mass of a thousand grains, spike grains mass and grain yield.Significant interactions between three-way cross maize hybrids and growing environments are verified for plant height, spike insertion height and prolificity.

The traits spike diameter, mass of a thousand grains and mass of grains per spike present positive correlation with maize grain yield.

The distinction of three-waycrosshybrids is based on spike insertion height, spike diameter, plant height and mass of a thousand grains. The hybrids $2 \mathrm{~B} 688 \mathrm{HX}^{\mathbb{B}}$ and $2 \mathrm{~A} 55 \mathrm{HX}^{\mathbb{B}}$ are genetically closer, according to the biometric approach of canonical variables.

\section{References}

Abuzar, M. R., Sadozai, G. U., Baloch, M. S., Baloch, A., Shah, I. H., Javaid, T., \& Hussain, N. (2011). Effect of plant population densities on yield of maize. The Journal of Animal \& Plant Sciences, 21, 692-695.

Balbinot, J. R., Alvadi, A., Backesr, L., Alvesa, C., Ogliari, J. B., \& Fonseca, J. A. (2005). Contribution of Yield Components on Grain Yield in Maize Open Pollinated Varieties. Revista Brasileira de Agrociência, 11, 161-166.

Carvalho, I. R., Nardino, M., Demari, G. H., Szareski, V. J., Follmann, D. N., Pelegrin, A. J., ... Souza, V. Q. (2017). Relations among phenotypic traits of soybean pods and growth habit. African Journal of Agricultural Research, 12(6), 450-458. https://doi.org/10.5897/AJAR2016.11660

Carvalho, I. R., Nardino, M., Pelegrin, A. J., Ferrari, M., Demari, G. H., Szareski, V. J., ... Souza, V. Q. (2016). Path analysis and Annicchiarico method applied in relation to protein in corn grains. Australian Journal of Basic and Applied Sciences, 10(9), 300-306. 
CONAB (Companhia Nacional de Abastecimento). (2016). Acompanhamento da safra brasileira de grãos. $10^{\circ}$ Levantamento Grãos Safra 2015/16.

Costa, E. F. N., Souza, J. C., Lima, J. L., \& Cardoso, G. A. (2010). Genotype $\times$ environment interaction in different types of maize hybrids. Brazilian Journal of Agricultural Research, 45, 1433-1440.

Cruz, C. D. (2013). Genes - A software package for analysis in experimental statistics and quantitative genetics. Acta Scientiarum Agro, 35, 271-276. https://doi.org/10.4025/actasciagron.v35i3.21251

Cruz, C. D., Regazzi, A. J., \& Carneiro, P. C. S. (2012). Modelos biométricos aplicados ao melhoramento genético. Viçosa: UFV.

Cruz, J. C., Pereira Filho, I. A., Alvarenga, R. C., Gontijo Neto, M. M., Viana, J. H. M., Oliveira, M. F., ... Albuquerque Filho, M. R. (2010). Cultivo do Milho. Embrapa milho e sorgo. Sistema de Produção (6th ed.). Versão Eletrônica.

Daros, M., Amaral Júnior, T. A., Pereira, M. G., Santos, S. F., Scapim, A. C., Freitas Júnior, P. S., ... Ávila, M. R. (2004). Correlations among agronomic traits in two recurrent selection cycles in popcorn. Rural Science, 34, 1389-1394. https://doi.org/10.1590/S0103-84782004000500010

Demari, G., Carvalho, I. R., Nardino, M., Szareski, V. J., Dellagostin, S. M., Rosa, T. C., ... Souza, V. Q. (2016). Importance of Nitrogen in Maize Production. International Journal of Current Research, 8(8), 36629-36634.

Demetrio, C. S. (2008). Desempenho agronômico de hibridos de milho em diferentes arranjos populacionais em Jaboticabal-SP (p. 68, Dissertação, Mestrado, Universidade Estadual Paulista “Júlio De Mesquita Filho").

Emygdio, B. M., Ignaczak, J. C., \& CargneluttiFilho, A. (2007). Yield potential of single, three-way and double cross commercial hybrids maize. RevistaBrasileira de Milho e Sorgo, 6, 95-103. https://doi.org/10.18512/ 1980-6477/rbms.v6n1p95-103

Falconer, D. S., \& Mackay, T. F. C. (1996). Introduction to quantitative genetics (4th ed., p. 464). Edinburgh: Longman Group Limited.

Fancelli, A. L., \& Dourado Neto, D. (2000). Ecofisiologia e fenologia. In A. L. Fancelli, \& D. Dourado Neto (Eds.), Produção de milho (pp. 21-54). Guaíba: Agropecuária.

Fancelli, A. L., \& Dourado Neto, D. (2000). Fisiologia da Produção e aspectos básicos de manejo para alto rendimento. In I. E. Sandini, \& A. L. Fancelli (Eds.), Milho, estratégias de manejo para a região Sul (pp. 103-114). Guarapuava: FAPA.

Ferrari, M., Nardino, M., Carvalho, I. R., Pelegrin, A. J., Meira, D., Szareski, V. J., ... Souza, V. Q. (2016). Morphological and yield components of wheat due to the splitting and sources nitrogen. Australian Journal of Basic and Applied Sciences, 10(15), 242-249.

Galon, L., Tironi, S. P., Rocha, A. A., Soarese, R., Concenço, C., \& Alberto, C. M. (2010). Influence of abiotic factors on maize crop productivity. Revista Trópica-Ciências Agrárias e Biológicasdo CCAA-UFMA, 4, 18-38.

Kendall, M. G. (1950). Factor analysis as a statistical technique. Journal Royal Statistical Society, $22,60-73$.

Li, Y., Dong, Y., Niu, S., \& Cui, D. (2007). The genetics relationships among plant-height traits found using multiple trait QTL mapping of a dent corn and popcorn cross. Genome, 50, 357-364. https://doi.org/ 10.1139/G07-018

Lopes, S. J., Dal'col, A. L., Storck, L., Damo, H. P., Brum, B., \& Santos, V. J. (2007). Path analysis on maize spikes characteristics related of the hybrid type. Ciência Rural, 37, 1536-1542. https://doi.org/10.1590/ S0103-84782007000600005

Maia, M. C. M., Vello, N. A., Rocha, M. M., Pinheiro, J. B., \& Silva Júnior, N. F. (2006). Adaptability and stability of soybean experimental lines selected for agronomic traits and insect resistance by uni-multivariate method. Bragantia, 2, 215-226. https://doi.org/10.1590/S0006-87052006000200004

Maluf, J. R. T. (2000). A new climatic classification for the State of Rio Grande doSul, Brazil. Brazilian Journal of Agrometeorology, 8, 141-150.

Miranda, G. V., Coimbra, R., Godoy, C., Souza, L., Guimarães, L. J., \& Melo, A. (2003). Potential to breeding and genetic divergence in popcorn cultivars. Brazilian Journal of Agricultural Research, 38, 681-688. 
Nardino, M., Baretta, D., Carvalho, I. R., Ferrari, M., Pelegrin, A. J., Szareski, V. J., ... Souza, V. Q. (2017). Genetic divergence among corn (Zea mays L.) genotypes in distinct nvironments. Revista de Ciências Agrárias (Lisboa), 40(1), 164-174. https://doi.org/10.19084/RCA16013

Nardino, M., Baretta, D., Carvalho, I. R., Follmann, D. N., Konflanz, V. A., Souza, V. Q., ... Maia, L. C. (2016). Phenotypical, genetic and environmental correlations between hybrid corn characters of the southern region of Brazil. RevistaBrasileira de Biometria, 34, 379-394.

Nardino, M., Baretta, D., Carvalho, I. R., Olivoto, T., Follmann, D. N., Szareski, V. J., ... De Souza, V. Q. (2016). Restricted maximum likelihood/best linear unbiased prediction (REML/BLUP) for analyzing the agronomic performance of corn. African Journal of Agricultural Research, 11(48), 4864-4872. https://doi.org/ 10.5897/AJAR2016.11691

Oliboni, R. (2009). Capacidade combinatória e divergência genética entre híbridos comerciais de milho recomendados para a região centro-sul do Paraná (p. 109, Dissertação, Mestrado, Universidade Estadual do Centro-Oeste, Guarapuava).

Paixão, S. L. (2008). Divergência genética e avaliação de populações de milho em diferentes ambientes no estado de Alagoas (p. 22, Dissertação, Mestrado em Agronomia, Centro de Ciências Agrarias, Universidade Federal de Alagoas, Alagoas).

Ramalho, M., Santos, J. B., Pinto, C. B., Souza, E. A., Gonçalves, F. M. A., \& Souza, J. C. (2012). Genética na Agropecuária (p. 565).

Ribeiro, C. B. (2012). Caracteres que explicam a heterose na produtividade de grãos de milho (p. 64, Dissertação, Mestrado, Universidade Federal de Lavras, Lavras).

Rotili, E. A., Cancellier, L. L., Dotto, M. A., Carvalho, E. V., \& Peluzio, J. M. (2012). Genetic divergence in populations of maize, in Tocantins State, Brazil. Revista Ciência Agronômica, 43, 516-521. https://doi.org/10.1590/S1806-66902012000300014

Sangoi, L., Schweitzer, C., Schmitt, A., Picoli, J. R. G. J., Vargas, V. P., Vieira, J., ... Carniel, G. (2010). Tillering and prolificacy as stabilizing traits to maize grain yield at different densities. Revista Brasileira de Milho e Sorgo, 9, 254-265. https://doi.org/10.18512/1980-6477/rbms.v9n3p254-265

Santos, H. G., Jacomine, P. K. T., Anjos, L. H. C., Oliveira, V. A., Oliveira, J. B., Coelho, M. R., ... Cunha, T. J. F. (2006). Sistema brasileiro de classificação de solos (p. 306). Rio de Janeiro: Embrapa Solos.

Shapiro, S. S., \& Wilk, M. B. (1965). An analysis of variance test for normality (complete samples). Biometrika, 52, 591-611. https://doi.org/10.1093/biomet/52.3-4.591

Silva, K. C. L., \& Peluzioj, M. (2014). Divergência genética entre genótipos de milho em Gurupi-TO (pp. 1-5). $10^{\circ}$ Seminário de iniciação científica da UFT. Palmas. Palmas: UFT.

Singh, D. (1981). The relative importance of characters affecting genetic divergence. The Indian Journal of Genetic and Plant Breeding, 41, 237-245.

Singh, R., Ram, L., \& Srivastava, R. P. (2012). A Journey of Hybrids in Maize: An Overview. Indian Research Journalof Extension Education, 1, 340-344.

Steel, R. G. D., \& Torrie, J. H. (1997). Principles and procedures of statistics: A biometrical approach (3rd ed., p. 666). New York: McGraw Hill Book.

Szareski, V. J., Carvalho, I. R., Kehl, K., Levien, A. M., Nardino, M., Demari, G. H., ... Aumonde, T. Z. (2017). Univariate, multivariate techniques and mixed models applied to the adaptability and stability of wheat in the Rio Grande do Sul State. Genetics and Molecular Research, 16(3), 1-13. https://doi.org/10.4238/ gmr16039735

Szareski, V. J., Carvalho, I. R., Kelh, K., Pelegrin, A. J., Nardino, M., Demari, G. H., ... Souza, V. Q. (2018). Interrelations of Characters and Multivariate Analysis in Corn. Journal of Agricultural Science, 10(2), 187-194. https://doi.org/10.5539/jas.v10n2p187

Szareski, V. J., Carvalho, I. R., Nardino, M., Demari, G. H., Bahry, C. A., Kehl, K., ... Aumonde, T. Z. (2016). Phenotype stability of soybean genotypes for characters related to the physiological quality of seeds produced under different environmentall conditions. Australian Journal of Basic and Applied Sciences, $10(15), 279-289$. 
Uitzil, A. M. P., Souza, V. Q., Olivoto, T., Nardino, M., Carvalho, I. R., Ferrari, M., ... Demari, G. (2016). Yield components of hybrid based on the plant population and artificial defoliation. Australian Journal of Basic and Applied Sciences, 10(10), 136-142.

USDA (United States Department of Agriculture). (2016). Statistics of grain and feed. Retrieved from https:/www.nass.usda.gov/Publications/Ag_Statistics/2015/Chapter01.pdf

\section{Copyrights}

Copyright for this article is retained by the author(s), with first publication rights granted to the journal.

This is an open-access article distributed under the terms and conditions of the Creative Commons Attribution license (http://creativecommons.org/licenses/by/4.0/). 